\title{
New educational technologies as a means of cross - regional cooperation in the field of food raw material and product safety control
}

\author{
$J G$ Bazarnova $^{1}, N T$ Zhilinskaya $^{2, *}, T V$ Pilipenko $^{1}, E S$ Belokurova $^{1}, O B$ Ivanchenko $^{1}$,and $V V$ Loboda $^{1}$ \\ ${ }^{1}$ Peter the Great St.Petersburg Polytechnic University (SPbPU), St.Petersburg, Russia \\ ${ }^{2}$ N.N. Petrov National Medical Research Center of Oncology, St.Petersburg, Russia
}

\begin{abstract}
International e-learning resource in the field of food product quality and veterinary disease control based on Government requirements of the European Union and Eurasian Economic Union has been created and tested. This resource consists of the one general professional cycle and five professional modules, about $60 \%$ of them are in distance e-learning format. The modularity of the educational resource allows the employer or students to choose a training program format, as well as the amount of distance learning or classroom training hours for different groups of specialists in the field of food quality and veterinary control: chiefs of quality control center or laboratories, veterinarians, microbiologists, specialists of veterinary diagnostics laboratories, chemical engineers. The involvement of participants from EU and EEU-countries in the educational process is important for the development of interregional and international activities, the creation of the unified legal framework in the field of food security in many countries.
\end{abstract}

\section{Introduction}

Protecting the health of humans, plants and animals at every stage of the food production process is a key public health and economic priority. The European Union (EU) food safety policy aims to ensure that EU citizens enjoy safe and nutritious food produced from healthy plants and animals, whilst enabling the food industry - Europe's largest manufacturing and employment sector - to operate in the best possible conditions. The fundamental document of the European Union in the field of food safety is the Regulation N 178/2002 of the European Parliament and of the Council of the European Union of 28 January 2002 [1, 2]. Regulation is intended to establish general principles and requirements in food law, general concepts of food legislation at the EU level, as well as to ensure a consistent approach in the development of national food legislation of the EU member states. Regulation also establishes the European food safety authority (EFSA).

Article 1 of the Eurasian Economic Union (EEU) Agreement (May 29, 2014) provides the creation of common markets for goods, services, capital and labor, as well as a common policy in various economic sectors $[3,4]$. For these economic integration projects the sphere of education is cross-cutting, covering a variety of interaction points [5].

The problem of a common educational market aimed to improve the quality of human capital and competitiveness is topical.

One of the important question of higher education and professional development system is the training of specialists and experts in customs, technical regulation, food product and raw material quality control, etc. Such specialist training is necessary for the associated economic institutions, EU and EEU public authority, as well as for business to ensure the development of new opportunities in the legal economic integration [6].

Currently, in all progressive countries all over the world much attention is paid to the human capital formation as an important component of modern society development [7]. Special role in the formation of such human capital is given to educational technologies.

Innovation technologies in higher education are necessary to meet the changing needs of the job market and to respond the international education trends.

Currently Russia continues the process of gradual transition to a level higher education, and new educational program formats are being introduced. In new educational programs much more attention is paid to the development of student personal and professional skills.

Therefore, the main target settings in modern educational standards is the competence approach. The term "competence" means the ability to apply knowledge, skills and personal qualities for successful activity in a certain professional area $[8,9]$.

Peter the Great St. Petersburg Polytechnic University ( $\mathrm{SPbPU}$ ) is the competence center of the national technological initiative "New production technologies".

Digitalization of educational technologies includes an interactive format of classroom sessions: round tables, case studies and master classes using the modular principle in educational programs, inclusion of distance

* Corresponding author: zhilinskaya nt@spbstu.ru 
learning modules and interdisciplinary projects in the curriculum aimed at the formation of student individual educational trajectory.

Lectures in the format of visualization go into the past and acquire the format of discussions, round tables and cases related to the analysis of real problem situations in the relevant field of professional activity and solution searching.

Interdisciplinary course projects are introduced into the curriculum for better practical component skill's mastery $[10,11]$.

At the same time, a University graduate, even well trained in professional terms and adapted to the realities of the world community, must constantly improve his skills to remain a modern specialist and keep up with the needs of the time. In this regard, the role of additional professional education (APE) as a system that allows the specialist to be continuously adapted to technological and socio-economic changes is significantly increasing. APE system is focused on close connection with changes in the real economy sector, production, non-material production sphere. APE system fulfills the individual need in continuing professional education.

The numerous projects of SPbPU proposed for implementation by means of APE system are very diverse. The need for their creation is caused by the integrative cooperation between Russia and EU-EEU countries. One of the main problems of modern society is to ensure the food raw materials and food product safety $[12,13]$.

The existing required sanitary and hygienic norms do not give a full guarantee of food safety. The increasing consumer requirements and the emerging food company needs have led to the creation and implementation of effective food safety management system, in which a special place is given to the control of food safety.

Currently, the control of physicochemical indicators and food product and food waste indicators includes verification their compliance with the requirements of regulating documents for the content of heavy metals, radionuclides, pesticides, other chemical pollutants, pathogens, protozoa, helminths and biological toxins that could be harm for human health $[14,15]$.

Speaking about the global question of improving food product quality and safety, it should be noted that in February, 2019, the first international conference on food safety was held in Ethiopia (Addis Ababa).In April, 2019, the first international forum on food safety and trade was held in Geneva. The objectives of these activities were to identify key measures and strategies to ensure current and future food safety on an international scale.

Thus the relevance of the educational resource in the field of food product quality control and food raw material veterinary examination for compliance with the requirements of the EU-EEU countries is due to the urgent need for learning highly qualified specialists in the field of safety control both in the inner market of the EU-EEU countries and products coming for export [16].

\section{Methods}

"Scientific abstraction", "system analysis", "comparative analysis".

Training modules included in the basic and additional educational programs are implemented using distance learning technologies: training on webinars, participation in professional forums, competitions, projects. Educational programs are implemented also by electronic lecture notes in the MOODLE system, as well as in a technological interactive learning environment (Smart-technology) [17]. This is facilitated by the fact that bachelors, master degree students, postgraduates and students-participants of additional educational programs studying in the SPbPU are representatives of various Russian Federation regions, near and far abroad.

\section{Results}

In 2017-2018, one of SPbPU projects in APE-system was the creation of an International educational resource in the field of food quality and safety control. This project was developed under the order of the Fund of infrastructure and educational programs (RUSNANO group). The project showed the possibility of successful cooperation between educational institutions of the EEU countries and Russian manufacturers of modern analytical equipment and devices for quality and food safety control. The project was developed by the staff of the Graduate school of biotechnology and food science and the Graduate school of applied physics and space technologies of Peter the Great St. Petersburg Polytechnic University.

Total volume of the International educational resource is 320 hours, of which at least $60 \%$ is devoted to distance learning. Modularity is one of the advantages of the educational resource, as it allows students to choose an individual educational trajectory, as well as the number of interdisciplinary courses aimed at the following target groups of specialists: heads of quality control laboratories and centers, veterinarians, engineermicrobiologists, specialists of veterinary diagnostics laboratories, chemical engineers, radiation control engineers.

The international electronic educational resource (hereinafter referred to as the Resource) in the field of food quality control and veterinary examination includes 1 general professional and 5 professional modules. The structure of the electronic training course of the Resource (ETC) includes training modules consisting of 24 interdisciplinary courses, which are independent elements of the Resource structure and could be assigned to students for the individual educational result formation. Distance module consists of theoretical training modules and teaching materials. Classroom lessons have two formats. The first format consists of lectures, practical and laboratory classes, master classes and testing for intermediate and final student's certification in order to check the acquired knowledge and skills. The second format consists of practical tasks to check the acquired new professional competencies. 
General professional cycle includes learning materials for student self-development in the ETC format: the regulatory framework for testing and calibration laboratories, safety and quality management system of food products (HACCP), information on the practical application of the validation principles and analytical method verification to assess their effectiveness during laboratory certification.

Professional modules include lectures and practical classes on research automated accounting, using RFIDtechnologies in veterinary laboratories and laboratories of food quality control; the procedure of food sample preparation as well as the practice of modern analytical methods for the identification and determination of chemicals, pesticides, antibiotics, toxic element contents and GMO components in food raw materials, feed and food; the procedure for the control implementation in accordance with the EU and EEU requirements as well as radiation control methods and food product radiation monitoring.

Separate interdisciplinary courses of professional modules represent a theoretical course or a practical guide to modern analysis methods, including both traditional microbiological methods of analysis and express tests with immunological and molecular detection methods, gas and high-performance liquid chromatography methods using for the target microbiological component identification.

Testing of the International educational resource was held in February 2019, in Vitebsk State Technological University (Republic of Belarus). 102 students from the Russia and EEU countries took part in three professional development programs: "Instrumental methods for quality control and food product safety", "Classical and express microbiological methods for the food product safety monitoring", "Methods and means of radiation control and monitoring".

On the lesson students acquired new skills in working with modern equipment used in sampling for microbiological, physicochemical and radiologic researches.

Equipment providers have presented modern devices and consumable materials on master classes. Students worked in two-person group which contributed to a more complete program learning.

Student interviews at the end of the training showed that the testing was carried out at a high methodological and professional level. All students have successfully mastered professional competence and gained the necessary experience of practical activity.

Such type of the International electronic educational resource allows train highly qualified specialists in their field able to solve important practical problems and ready for career progress [18].

The experience of pilot International educational resource implementation allowed to identify some following risks such as:

-marketing of Resource educational programs on the EEU territories;

-differences in the legal framework in Russian Federation and in EU-EEU countries in organization of specialist training; -student recruitment and enrollment from the EEU countries, the document processing.

\section{Conclusion}

The involvement of students from the EEU and EU countries in the learning process is very important for the development of cross regional and international activities, the creation of a unified legal framework in the field of food security of the partner countries.

The knowledge dissemination, possibly through new approaches and the introduction of best educational practices in teaching, promotes closer interaction in understanding the importance of food product safety which undoubtedly contributes to the social and economic interaction between EU-EEU countries.

Training of target group qualified specialists will improve the efficiency of inter-regional and inter-state safety control of food products and animal feed, will increase the product competitiveness on foreign market and socio-economic region development in improving the level of food raw material and food product safety.

\section{References}

[1] Regulation of the European Parliament and of the Council of the European Union of 28 January 2002, no. 178/2002 "On the establishment of General principles and regulations of food legislation, on the establishment of a European food safety authority and on the consolidation of procedures for the safety of food products" [Electronic resource]. Available at: https://base.garant.ru/2565753/\#friends

(Accessed: 03.05.2019).

[2] Regulation (EC), no. 178/2002 of the European Parliament and of the Council of 28 January 2002 laying down the general principles and requirements of food law, establishing the European Food Safety Authority and laying down procedures in matters of food safety, Official Journal, L 031, 0001-0024 (02.01.2002) [Electronic resource]. Available at: https://eurlex.europa.eu/legalcontent/EN/ALL/?uri=CELEX:32002R0178 (Accessed: 28.04.2018).

[3] The Treaty on the Eurasian Economic Union (signed in Astana on 29.05.2014) [Electronic resource]. Available at: http://www.consultant.ru/documents/cons doc L AW 163855/ (Accessed: 09.12.2018).

[4] M.T. Nurgalieva, A.K. Smagulov, Z.A. Iskakova, The issues of quality and safety control of food products in the frame of EU and EEU, J. Science and World, 31, 86-91 (2018).

[5] S.T. Azimova, M.Z. Kizatova, S.O. Akhmetova, L.V. Donchenko, A.M. Admayev, Towards food security through application of novel scientific findings, J. of Security and Sustainability Issues (Lithuania), 4, 719-728 (2017). 
[6] S.M. Yun, Education as a sphere of cooperation within the Eurasian Economic Union: problems and prospects, J Bulletin of Tomsk state University, History (in Russia), 50, 89-92 (2017).

[7] E. Razinkina, L. Pankova, I. Trostinskaya, E. Pozdeeva, L. Evseeva, A. Tanova, Student satisfaction as an element of education quality monitoring in innovative higher education institution, E3S Web of Conferences, 33, 3-43 (2018) DOI: $10.1051 / \mathrm{e} 3$ sconf/20183303043.

[8] E.S. Belokurova, I.A. Pankina, The role of nutrition in the formation of human capital, The European Proceedings of Social \& Behavioural Sciences (EpSBS), L1, 1367-1377 (2018). DOI: 10.15405/epsbs.2018.12.02.146.

[9] A.M. Alexankov, I.R. Trostinskaya, N.N. Pokrovskaia, Requirements for quality of human capital and competencies formed within educational institutions, The European Proceedings of Social \& Behavioral Sciences (EpSBS), 4, XXXIV-RPTSS, 26-34 (2018). DOI: 10.15405/epsbs.2018.02.4.

[10] N. Zhilinskaya, S. Eliseeva, N. Barsukova, I. Bazarnova, The role of interdisciplinary scientific research in forming specialists of food biotechnology, Proceedings of International scientific and practical conference 18 th PCSF Professional Culture of the Specialist of the Future, 03-04 December The European Proceedings of Social \& Behavioural Sciences (EpSBS), 1458-1466 (2018). DOI: 10.15405/epsbs.2018.12.02.155.

[11] J.G. Donald, The commons: Disciplinary and interdisciplinary encounters In C. Kreber, (Ed.), The university and its disciplines: Teaching and learning within and beyond disciplinary boundaries, Eds. New York and London: Routledge, Taylor \& Francis group, 35-49 (2009).

[12] N. Zhilinskaya, S. Eliseeva, E. Milovanovich, I. Bazarnova, Influence of Biopreparation "AlirinB" on Cytomorphometric Characteristics of Conidia of Fungus Fusarium spp, Causing Potato Dry Rot, Proceedings of International scientific and practical conference "AgroSMART - Smart solutions for agriculture", 151, 807-811 (2018). DOI: 10.2991/agrosmart-18.2018.151.

[13] O.B. Ivanchenko, R.E. Khabibullin, R. Bhat, Wastewaters of meat-processing enterprise: assessment of genotoxic potentional, Proceedings of International Scientific Conference on Energy, Environmental and Construction Engineering (EECE-2018), MATEC Web Conf., Article Number 18002, 6 (2018). DOI: 10.1051/matecconf/201824518002.

[14] Technical Regulations of the Customs Union TR CU 021/2011 "On Food Safety" [Electronic resource]. Available at: http://www.eurexcert.com/TRCUpdf/TRCU0021-On-food-safety.pdf (Accessed: 02.05.2019).

[15] O. Ivanchenko, O. Baranova, M. Danina Contamination of Malting Barley by Toxigenic Fungi of Genera Fusarium and Cochliobolus,
Proceedings of the International Conference on Smart Solutions for Agriculture (Agro-SMART 2018), 151, 290-296 (2018).

[16] Y.G. Bazarnova, I.V. Samorukov, N.T. Zhilinskaya, O.B. Ivanchenko, Innovative technologies in additional professional education on the microbiological safety of food and biotechnological products, Proceedings of the I International scientific and practical conference "Veterinary and sanitary aspects of quality and safety of agricultural products" (in Russia), Voronezh: Peter the First Voronezh State Agrarian University, 225-228 (2015).

[17] N.G. Viktorova, E.V. Evstigneev, N. Pankova, Department of the University: present and future (in Russia), J. The mission of the University of the XXI century, 12, 52-58 (2013).

[18] L.M. Borisova, E.S. Belokurova, S.A. Lopatin, Health-Saving technologies as preventive measures to preserve and strengthen the health of University students, J. Life Safety, 8, 21-26 (2014). 